\title{
IMPLEMENTASI PEMBEKALAN PRANIKAH DALAM MEMBENTUK KELUARGA SAKINAH MAWADDAH WA RAHMAH
}

\author{
Mahmudin \\ Program Pasca Sarjana FIAI UII Yogyakarta \\ Email: mahmudinhulu@gmail.com
}

\section{Abstract}

One important factor in the preparation for marriage is a matter of debriefing before marriage for the bride and groom. This affects the readiness of the bride and groom to wade living together in a household. The program is expected to prospective brides can achieve a teaching / guidance in preparation to perfection and completeness of the meaning of life and living in a happy household. Household sakinah is the family life which is fostered by the marriage valid, capable of fulfilling the lives of spiritual and material worthy, capable of creating an atmosphere of affection (mawaddah warahmah) harmonious, and balanced and able to embed and implement the values of faith, devotion, and charitable pious and akhlakul karimah within the family according to the teachings of Islam. This is important because many divorces happened lately caused by misunderstanding interminable, unpreparedness in a foster home, and small habits that are not favored by the opposite sex.

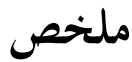

أحد العوامل الهامة في التحضير للزواج هي مسألة استخلاص المعلومات قبل الزواج للعروس والعريس. هذا يؤثر على استعداد العروس والعريس ليعيشا معا في منزل. ومن المتوقع، يمكن البرنامج للعرائس المقبلينتحقيق التدريس/التوجيه في إعداد لكمال واكتمال معنى الحياة والعيش في أسرة سعيدة. السكينة المنزلية هو الحياة الأسرية التي رسخها النكاحالصحيح والقادرة على إستحقاقوفاء الحياة الروحية والمادية،والقادرة على خلق جو من المودة والرحة، والمتوازنة والقادرة على ترسيخ وتنفيذ قيم الإيمان 


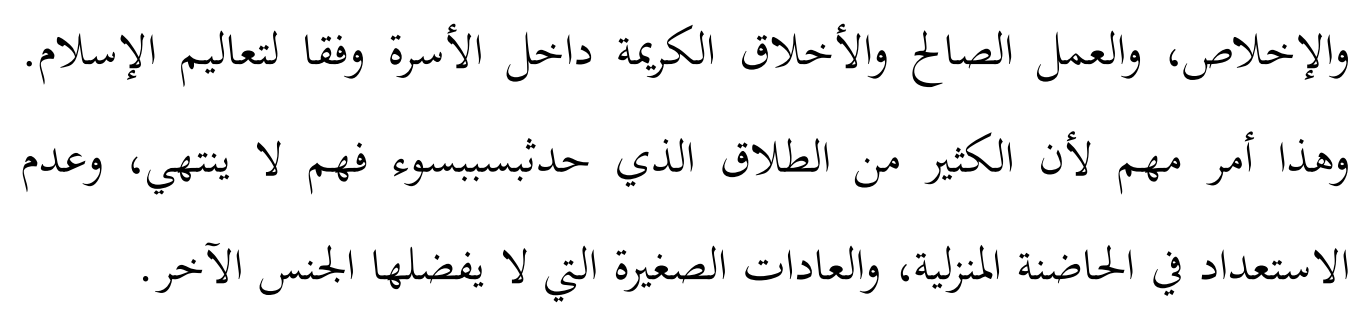

Keywords : Pembekalan, Pra Nikah, Implementasi

\section{A. Pendahuluan}

Pernikahan adalah suatu ikatan diantara dua orang manusia antara laki laki dan perempuan diikuti percampuran dua keluarga yang berbeda latar belakang baik dari segi ekonomi, kebudayaan dan lainnya. Secara psikologis pernikahan diharuskan penyatuan sepasang manusia secara emosional dengan karakteristik yang berbeda dimana dalam penyatuan tersebut begitu banyak memerlukan perjuangan karena secara fitrah manusia itu memiliki kepribadian yang berbeda. ${ }^{1}$

Pernikahan berkualitas adalah kondisi dimana dengan pernikahan dapat menghasilkan kebahagiaan, kesesuaian serta kestabilan pernikahan. Sedangkan tingkat kualitas pernikahan sendiri dipengaruhi oleh faktor seperti komposisi optimal keluarga, siklus kehidupan keluarga, kelayakan sosio ekonomi dan kesesuaian peran, faktor sumber daya sosial dan pribadi suami istri bahkan oleh kondisi pranikah. Islam memandang bahwa pernikahan berkualitas akan diukur dari proses pra, pas, dan pasca nikah. Bagaimana seseorang memulai proses dari mencari calon istri atau suami hingga sampai akad nikah dan pasca nikah akan mempunyai keturunan, kesemuanya itu dibalut dalam syariat yang jelas. Sehingga harapannya ketika mempunyai keturunan, adalah anak yang sholeh dan sholehah, bisa memberikan kebermanfaatan untuk umat.

Keluarga memang menjadi tempat paling penting dalam penanaman ilmu keislaman. Karena di sinilah anak akan belajar untuk pertama kalinya sebelum memperoleh ilmu dari luar lingkungan keluarga. Kerjasama yang baik antara

1 Suhartini. "Pentingnya Pendidikan Pra Nikah", dikutip dari http:/ / www.shvoong.com. /makalah/pada hari Sabtu tanggal 15 Maret 2014, jam. 12.30 WIB. 
ayah dan ibu sangat vital dalam proses tumbuh kembang anak. Akan tetapi, peran keluarga sebagai institusi pendidikan non formal juga harus mendapat dukungan dari institusi pendidikan formal mulai dari dasar hingga tingkat lanjutan. Seperti dijelaskan di awal, bahwa pernikahan adalah hal rumit dan ini harus dipaparkan dengan gamblang dari yang bersifat umum hingga mendetail bagaimana Islam mengatur hal tersebut. Mungkin ada permasalahan yang orang tua belum bisa menyampaikan dan harus disampaikan oleh yang lebih ahli dan berilmu. Untuk membentuk keluarga yang sakinah mawaddah warahmah sudah seharusnya kepada setiap calon pengantin berhak untuk mendapatkan pembekalan yang cukup dari instansi atau lembaga terkait yang berkecimpung di bidang pernikahan sebagai modal awal dalam mengarungi samudera kehidupan rumah tangga, agar selamat dari goncangan ombak yang akan menerpanya.

Calon pengantin perlu mendapatkan pembekalan dan pemahaman tentang syarat keluarga yang berkualitas. keluarga berkualitas tidak dilihat dari jumlah anak, namun yang terpenting adalah kualitas pendidikan, kesehatan, dan kesejahteraannya. Agar setiap keluarga berkualitas mampu membangun dirinya secara mandiri minimal harus mampu menghayati, memiliki dan berperan dalam fungsi-fungsi keluarga diantaranya norma agama, nilai sosial budaya, membangun cinta kasih dalam keluarga, mengatur reproduksinya, dan memelihara lingkungan serta alam.

Calon pengantin perlu mendapatkan pembekalan tentang norma agama agar bisa menjadi landasan falsafah yang amanah dari kehidupan yang penuh iman kepada Tuhan Yang Maha Esa. Kualitas suatu bangsa sangat ditentukan oleh kualitas keluarga sebagai unit terkecil dari masyarakat. Calon pengantin perlu mendapatkan pemahaman tentang menjunjung tinggi nilai-nilai sosial dan budaya yang dianut oleh keluarga lain dan saling hormat menghormati nilai budaya yang berjalan. Calon pengantin perlu diberikan pengetahuan bahwa keluarga harus saling memiliki rasa cinta kasih dalam melaksanakan berbagai hal yang terwujud dalam perilaku, tutur kata dan perbuatan sehari-hari. Saling mencintai adalah kemampuan yang harus selalu dirawat dan dikembangkan dalam keluarga. Calon pengantin perlu mendapat wawasan tentang ekonomi rumah tangga karena selama ini persoalan ekonomi menjadi penyebab terbesar terjadinya kasus-kasus kekerasan dalam rumah tangga. Dengan kemandirian 
perempuan dalam keluarga, sehingga bisa mengentaskan keluarga dari keterbatasan ekonomi merupakan salah satu upaya yang bisa dipakai untuk menekan angka kekerasan dalam rumah tangga.

Keluarga merupakan tempat untuk pendidikan dan pembentukan watak, moral, serta melatih kebersamaan sebagai bekal kehidupan bermasyarakat, berbangsa dan bernegara. Keluarga juga merupakan tempat bermuara dan berlabuhnya semua persoalan sosial kemasyarakatan. Sehingga diperlukan kedamaian dan ketenangan suasananya. Keluarga juga merupakan tempat untuk saling memberi kehangatan, perlindungan dan cinta kasih. Keluarga merupakan unsur terkecil dari masyarakat. Kesejahteraan, ketentraman dan keserasian keluarga, sangat tergantung kepada perilaku pribadi masing-masing anggota keluarga tersebut, sedangkan keluarga terbentuk melalui perkawinan. Tujuan perkawinan bagi pasangan suami-istri adalah untuk menciptakan kehidupan rumah tangga yang harmonis, penuh kasih sayang, bahagia dan sakinah mawadah wa rahmah. Untuk mencapai tujuan tersebut, maka diperlukan persiapan pra-nikah dan pasca nikah yang mapan dan terencana, sehingga tujuan tersebut akan mudah dicapai.

Secara terperinci pembekalan pra nikah diarahkan pada terwujudnya pengetahuan dan pemahaman calon pengantin akan pengetahuan tentang hukum perkawinan, keluarga, reproduksi sehat, pemecahan masalah-masalah keluarga, penanaman nilai keimanan, ketaqwaan, akhlakul karimah, tuntunan ibadah dan pendidikan agama dalam keluarga. ${ }^{2}$ Harapan yang diinginkan adalah bahwa setiap pasangan pengantin mampu untuk membentuk rumah tangga yang sakinah mawaddah warahmah, sehingga angka perceraian dapat diminimalisir semaksimal mungkin.

\section{B. Pembekalan Pra Nikah}

Pembekalan atau penasehatan secara ilmiah mempunyai pengertian tersendiri dan hanya dapat dilakukan oleh orang-orang tertentu yang menguasai ilmu tersebut. Pembekalan pra nikah juga termasuk penasehatan perkawinan, yaitu suatu pelayanan sosial mengenai permasalahan keluarga,

2 Dirjen Bimas Islam dan Penyelenggaraan Haji Kementerian Agama, Buku Pegangan Calon Pengantin, (Jakarta: Dirjen Bimas Islam dan Penyelenggaraan Haji Kementerian Agama, 2003), hal. 17-263 
khususnya hubungan suami isteri, tujuan yang hendak dicapai adalah terciptanya situasi yang menyenangkan dalam suatu hubungan suami isteri, sehingga dengan situasi yang menyenangkan tersebut keluarga dapat mencapai kebahagiaan. ${ }^{3}$ Menurut Abdul Kholiq, pengertian pembekalan pra nikah adalah pendidikan dan pengarahan kepada calon pengantin yang diadakan sebelum dilangsungkannya proses akad nikah, yang mencakup materi kebijakan pemerintah dalam bidang perkawinan, membentuk keluarga Islami, hukum munakahat dan etika perkawinan, serta membangun rumah tangga sakinah mawaddah warahmah. ${ }^{4}$

Melihat uraian diatas, dapat dikatakan bahwa yang dimaksud dengan pembekalan pra nikah adalah proses transformasi prilaku dan sikap di dalam kelompok atau unit sosial terkecil dalam masyarakat terhadap calon mempelai. Persiapan kearah perkawinan perlu dilakukan agar mereka yang akan memasukinya betul-betul siap, baik mental maupun material, terutama dalam mewujudkan fungsi-fungsi keluarga. Fungsi-fungsi keluarga itu adalah fungsi pengaturan seksual, fungsi sosialisasi, fungsi penentuan status, fungsi perlindungan dan fungsi ekonomi. ${ }^{5}$ Diluar fungsi tersebut ada fungsi utama yang tidak boleh dilupakan oleh seorang muslim yakni fungsi pengamalan agama. Dengan pengamalan agama tersebut, hati merasa tenang dan bahagia.

Persiapan perkawinan dilakukan melalui proses pembekalan yang cukup matang atau dengan kata lain melalui proses pendidikan, baik pembekalan itu dilaksanakan oleh keluarga maupun yang dilaksanakan oleh instansi terkait seperti Kantor Urusan Agama (KUA), atau yang dikenal dengan kursus calon pengantin. Pendidikan dalam arti luas, sempit atau luas terbatas adalah kegiatan yang menjembatani antara kondisi-kondisi aktual dengan kondisikondisi ideal, berlangsung dalam satuan waktu tertentu, merupakan langkahlangkah untuk mengubah kondisi awal sebagai masukan menjadi kondisi ideal sebagai hasilnya. ${ }^{6}$

3 Departemen Agama, Pedoman Pembantu Pegawai Pencatat Nikah, (Jakarta: Dirjen Bimas Islam da Penyelenggara Haji, 2004), hal. 58

4 Wawancara dengan Abdul Kholiq, Penghulu KUA Kecamatan Kemiri, tanggal 17 Pebruari 2014 di KUA Kec. Kemiri.

5 Jamil Sahrodi dkk, Membedah Nalar Pendidikan Islam, Pengantar kearah Ilmu Pendidikan Islam, (Cirebon: Pustaka Rihlah Group, 2005), hal. 76-78

6 Redja Mudyahardjo, Filsafat Ilmu Pendidikan, (Bandung: Rosda Karya, 2006), hal. 64 
Peserta pembekalan pra nikah adalah orang dewasa, minimal 16 tahun untuk perempuan dan 19 tahun untuk laki-laki dan telah menyiapkan diri untuk memasuki keluarga baru, maka dari sisi usia, pendidikan pra nikah masuk dalam kategori pendidikan kehidupan keluarga. Menurut Bryson, dkk mengatakan bahwa pendidikan orang dewasa adalah semua aktifitas pendidikan yang dilakukan oleh orang dewasa dalam kehidupan sehari-hari yang hanya menggunakan sebagian waktu dan tenaganya untuk mendapatkan tambahan intelektual. ${ }^{7}$ Menurut Bastomi mengutip pendapat Reeves dan Houle mengatakan bahwa pendidikan orang dewasa adalah suatu usaha yang ditujukan untuk mengembangkan diri yang dilakukan oleh individu tanpa paksaan legal, tanpa usaha untuk menjadikan bidang utama kegiatannya. ${ }^{8}$

Menurut Unesco pendidikan orang dewasa adalah keseluruhan proses pendidikan yang diorganisasikan, apapun isi, tingkatan, metodenya baik formal atau tidak, yang melanjutkan maupun menggantikan pendidikan semula disekolah, akademi dan universitas serta latihan kerja, yang membuat orang dianggap dewasa oleh masyarakat, mengembangkan kemampuannya, memperkaya pengetahuannya, meningkatkan kualifikasi teknis dan profesionalnya, dan mengakibatkan perubahan pada sikap dan perilakunya dalam rangka pengembangan sosial ekonomi, dan budaya yang seimbang dan bebas. ${ }^{9}$ Dilihat dari penekanan masing-masing definisi tersebut, kajian tentang pembekalan pra nikah diterapkan sebagai pendidikan orang dewasa dalam pengertian bahwa pendidikan pra nikah merupakan usaha yang tidak dipaksa dengan menggunakan sebagian waktu dan tenaganya untuk pengembangan individu dan peningkatan partisipasi sosial.

Perkembangan individu dan peningkatan partisipasi sosial merupakan penekanan yang penting dalam pendidikan di suatu keluarga. Karena kemunculan pendidikan kehidupan keluarga didasarkan pada adanya saling mempengaruhi antara kehidupan keluarga dan lingkungan. Hal ini menunjukkan bahwa kehidupan keluarga senantiasa berhadapan dengan

7 Suprijanto, Pendidikan Orang Dewasa dari Teori hingga Apikasi, (Jakarta: Bumi Aksara, 2007), hal. 13.

8 Wawancara dengan Bastomi (Kepala KUA Kec. Kemiri Kab. Purworejo) tanggal 20 Januari 2014 di Kemiri.

9 Suprijanto, Pendidikan Orang Dewasa dari Teori hingga Aplikasi, (Jakarta: Bumi Aksara, 2007), hal. 12-13. 
berbagai permasalahan yang berkembang dilingkungan sekitar, seperti pertambahan penduduk, ekonomi, gizi, perhatian terhadap wanita dan anakanak, perumahan dan lain-lain. ${ }^{10}$

Bidang garapan pendidikan kehidupan keluarga meliputi: hubungan dalam keluarga, penyadaran diri, pertumbuhan dan perkembangan anak, persiapan untukmemasuki pernikahan dan menjadi pemimpin dalam kehidupankeluarga, pemeliharaan anak, sosialisasi terhadap remaja dalam memasuki peran orang dewasa, pendidikan sex, manajemen sumber daya manusia dan harta keluarga, pendidikan kesehatan (individu, keluarga dan lingkungan), interaksi inter dan antar keluarga, serta pengaruh perubahan lingkungan terhadap kehidupan ekonomi, social dan budaya keluarga. ${ }^{11}$

Teori lain yang berdekatan dengan penyelenggaraan pendidikan pra nikah adalah teori pendidikan menjadi orang tua atau dikenal dengan parenting education. Diantara cakupan dalam pendidikan ini adalah menyangkut bagaimana peserta dapat mempersiapkan diri sebagai orang tua dan mendidik anaknya. Pembekalan pra nikah sangat diperlukan sebagai upaya untuk memberikan bimbingan dan arahan kepada pasangan calon pengantin guna mempersiapkan diri membentuk sebuah rumah tangga yang bahagia dan sejahtera lahir batin.

Rumah tangga bahagia (sakinah) adalah kehidupan keluarga yang dibina berdasarkan perkawinan yang sah, mampu memenuhi hajat hidup spiritual dan material yang layak, mampu menciptakan suasana kasih sayang (mawaddah warahmah) selaras, serasi seimbang serta mampu menanamkan dan melaksanakan nilai-nilai keimanan, ketakwaan, amal sholeh dan akhlakul karimah dalam lingkungan keluarga sesuai dengan ajaran agama Islam. ${ }^{12}$

\section{Membentuk Keluarga Sakinah}

\section{Keluarga Pra Sakinah}

Apabila terdapat kategori keluarga sakinah, maka dapat dipastikan

${ }^{10}$ HD. Sujana, Pendidikan Nonformal, Wawasan Sejarah Perkembangan Filsafat Teori Pendukung Asas, (Bandung: Falah Production, 2004), hal. 54.

11 Ibid, hal. 56-57

12 Keputusan Dirjen Bimas Islam dan Urusan Haji Kementerian Agama RI, Nomor D/71/1999, pasal 3. 
bahwa keluarga-keluarga yang tidak termasuk dalam kategori-kategori tersebut, belumlah atau tidak dapat disebut keluarga sakinah, dengan kata lain dapat disebut sebagai keluarga pra sakinah.Keluarga Pra Sakinah adalah keluarga yang dibentuk bukan melalui ketentuan perkawinan yang sah, tidak memenuhi kebutuhan dasar spiritual dan material (basic-need) secara minimal, seperti keimanan, shalat, zakat fitrah, puasa, sandang, pangan, papan dan kesehatan. ${ }^{13}$

Ciri utama keluarga pra sakinah adalah karena pembentukan keluarganya tidak melalui perkawinan yang sah, baik sah menurut agama maupun sah menurut undang-undang yang berlaku. Disamping ciri utama tersebut juga ditambah dengan ciri-ciri yang lain, yaitu: (a) Tidak memiliki dasar keimanan; (b) Tidak melaksanakan sholat wajib, zakat fitrah dan puasa wajib; (c) Tidak tamat SD dan tidak dapat baca tulis; (d) Termasuk dalam katagori keluarga miskin; (e) Berbuat asusila; dan (f) Terlibat perkaraperkara kriminal

Keluarga pra sakinah atau keluarga broken home yaitu keluarga yang dalam kehidupan keluarganya tidak mendapatkan kebahagiaan, baik secara spiritual maupun material. Keluarga tersebut tidak atau kurang memiliki keimanan dan ketaqwaan, tidak harmonis, tidak memiliki akhlak dan moral yang baik, sering bertengkar atau berselisih dalam keluarga. Hal-hal yang dapat mengakibatkan kehidupan rumah tangga tidak bahagia, dan perlu dihindari antara lain: (a) Membuka rahasia keluarga, (b) Cemburu berlebihan, (c) Rasa dendam, iri hati dan dengki, (d) Judi dan minuman keras, serta pergaulan bebas tanpa batas, (e) Kurang menjaga kehormatan diri. ${ }^{14}$ Keluarga pra sakinah juga dapat terjadi akibat perselisihan yang terus menerus antar pasangan. Hal ini dapat ditimbulkan akibat dari: (a) Mengulangi cerita lama/nostalgia pribadi, (b) Mengungkit-mengungkit kekurangan keluarga, (c) Suka mencela kekurangan suami/istri, dan memuji wanita / pria lain, dan (d) Kurang peka terhadap hal-hal yang tidak disenangi. ${ }^{15}$

13 Keputusan Dirjen Bimas Islam dan Urusan Haji Nomor D/71/1999, pasal 4

14 Departemen Agama, Membina Keluarga Sakinah, (Jakarta: Dirjen BMI dan PUH, 2003) hal. 50-52.

15 Ibid, hal. 52-54. 


\section{Upaya Membentuk Keluarga Sakinah}

Secara singkat dapat dikemukakan bahwa ada beberapa hal yang perlu ditempuh sebagai upaya guna mewujudkan cita-cita kearah tercapainya menggapai keluarga sakinah mawaddah warahmah, yaitu:

a. Mewujudkan harmonisasi hubungan antara suami dan isteri, hal ini dapat dilakukan dengan adanya; saling pengertian, saling menerima kenyataan, saling menyesuaikan diri, saling memupuk rasa cinta dan kasih, melaksanakan azas musyawarah, suka memaafkan, berperan serta dalam kemajuan bersama, menghormati keluarganya, saling menghargai, dan saling bersabar dalam menghadapi permasalahan dan mencari solusi

b. Membina hubungan antara anggota keluarga dan lingkungan. Keluarga dalam lingkup yang lebih besar tidak hanya terdiri dari ayah, ibu dan anak, akan tetapi menyangkut hubungan persaudaraan yang lebih besar lagi, baik hubungan antara anggota keluarga maupun hubungan dengan lingkungan masyarakat. Hubungan antara anggota keluarga, karena hubungan persaudaraan yang lebih luas menjadi ciri dari masyarakat kita, hubungan diantara sesama keluarga harus terjalin dengan baik antara keluarga dari kedua belah pihak. Suami harus baik dengan pihak keluarga isteri, demikian juga isteri harus baik dengan keluarga pihak suami. Hubungan dengan tetangga dan masyarakat, tetangga merupakan orang-orang terdekat yang umumnya merekalah orang-orang yang pertama tahu dan dimintai pertolongannya. Oleh karenanya sangatlah janggal kalau hubungan dengan tetangga tidak mendapat perhatian.

c. Melaksanakan pembinaan kesejahteraan keluarga. Dalam melaksanakan pembinaan kesejahteraan keluarga, ada beberapa hal yang dapat dilakukan, antara lain; keluarga berencara, usaha perbaikan gizi keluarga, imunisasi, dan menjaga kesehatan.

d. Membina kehidupan beragama dalam keluarga. Beberapa hal yang perlu diperhatikan dan diamalkan dalam kaitannya dengan pembinaan kehidupan beragama dalam keluarga, antara lain; melaksanakan sholat lima waktu secara berjamaah dalam keluarga atau mengajak keluarga untuk mengikuti sholat berjamaah di masjid 
atau di musholla, membiasakan taqorrup (mendekatkan) diri kepada Allah, membiasakan selalu berdzikir dan berdoa, membudayakan ucapan baik (kalimah thoyibah), membiasakan mengucapkan salam dan menjawabnya, menjawab seruan adzan, menyisihkan sebagian rizkinya untuk kepentingan Islam, gemar membaca al-Qur'an dan mengamalkannya, menghiasi rumah dengan hiasan yang bernafaskan Islam, berpakaian yang sopan sesuai dengan ajaran Islam, beretika yang baik dalam segala tingkah laku, baik di dalam rumah maupun diluar rumah, berusaha meninggalkan perbuatan-perbuatan yang dilarang oleh ajaran Islam, selalu beramar ma'ruf dan nahi mungkar, dan senantiasa tetap bertawakal kepada Allah SWT. ${ }^{16}$

\section{Pengertian Keluarga Sakinah}

Kata keluarga menurut sosiologi adalah kesatuan kemasyarakatan (sosial) berdasarkan hubungan perkawinan atau pertalian darah, yang selanjutnya dijelaskan bahwa keluarga merupakan unit terkecil dari suatu masyarakat. Kamus Besar Bahasa Indonesia mengartikan kata keluarga sebagai "sanak saudara, kaum kerabat, orang seisi rumah". ${ }^{17}$ Sedang kata sakinah diartikan sebagai: "damai, tempat yang aman". ${ }^{18}$ Kata sakinah

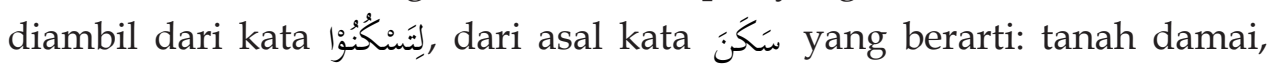
kemudian menjadi isim masdar wَكِيْنَ yang artinya ketenangan dan ketentraman hati. ${ }^{19}$

Menurut Muhammad Rasyid Ridha, sakinah adalah sikap jiwa yang timbul dari suasana ketenangan dan merupakan lawan dari kegoncangan batin dan kekalutan. ${ }^{20}$ Menurut al-Jurjani, sakinah adalah adanya ketentraman dalam hati pada saat datangnya sesuatu yang tidak diduga, dibarengi satu nur (cahaya) dalam hati yang memberi ketengangan dan ketentraman pada yang menyaksikannya dan merupakan keyakinan berdasarkan penglihatan. ${ }^{21}$

${ }_{16}$ Choirrul Jihad, Panduan Keluarga Muslim, (Semarang: BP4 Jateng, 2001), hal.10-13

17 Poerwadarminta, Kamus Besar Bahasa Indonesia, (Jakarta: Balai Pustaka, 1999), hal. 471.

18 Ibid, hal. 581.

19 Kementerian Agama, Tanya Jawab Seputar Keluarga Sakinah, (Jakarta: Dirjen Bimas Islam, 2006), hal. 20.

${ }^{20}$ Ibid, hal. 21.

${ }^{21}$ Ibid, hal. 22 
Rumah tangga bahagia atau keluarga sakinah adalah kehidupan keluarga yang dibina berdasarkan perkawinan yang sah, mampu memenuhi hajat hidup spiritual dan material yang layak, mampu menciptakan suasana kasih sayang (mawaddah warahmah) selaras, serasi seimbang serta mampu menanamkan dan melaksanakan nilai-nilai keimanan, ketaqwaan, amal sholeh dan akhlakul karimah dalam lingkungan keluarga sesuai dengan ajaran agama Islam..$^{22}$ Keluarga yang dibina menjadi keluarga sakinah adalah keluarga yang mawaddah, rahmah serta amanah.

Mawaddah adalah jenis cinta membara, yang menggebu-gebu, kasih sayang pada lawan jenisnya (rasa cinta yang didorong oleh kekuatan nafsu seseorang pada lawan jenisnya). Karena itu, setiap makhluk Allah kiranya diberikan sifat ini, mulai dari hewan sampai manusia. Mawaddah cinta yang lebih condong pada material seperti cinta karena kecantikan, ketampanan, bodi yang menggoda, cinta pada harta benda, dan lain sebagainya. Mawaddah itu sinonimnya adalah mahabbah yang artinya cinta dan kasih sayang. Warahmah berasal dari pemenggalan kata $\mathrm{Wa}$ artinya dan, sedangkan Rahmah berarti ampunan, anugerah, karunia, rahmat, belas kasih, rejeki. Jadi, rahmah adalah jenis cinta kasih sayang yang lembut, siap berkorban untuk menafkahi atau melayani dan siap melindungi kepada yang dicintai.

Rahmah lebih condong pada sifat qolbiyah atau suasana batin yang terimplementasikan pada wujud kasih sayang, seperti cinta tulus, kasih sayang, rasa memiliki, membantu, menghargai, rasa rela berkorban, yang terpancar dari cahaya iman. Sifat rahmah ini akan muncul manakala niatan pertama saat melangsungkan pernikahan adalah didasari karena ibadah, mengikuti perintah Allah dan sunnah Rasulullah serta bertujuan hanya untuk mendapatkan ridha Allah SWT. Amanah adalah sesuatu yang diserahkan kepada pihak lain disertai dengan rasa aman dari pemberinya, karena kepercayaannya bahwa apa yang diamanahkan itu akan dijaga dengan baik serta keberadaannya aman ditangan orang yang diberi amanah tersebut.

Menurut Sayid Quthub dalam Tafsir fi Dhilalil Qur'an Juz 21 menerangkan bahwa yang dimaksud dengan sakinah dan mawaddah

${ }^{22}$ Keputusan Dirjen Bimas Islam dan Urusan Haji Kementerian Agama RI, Nomor D/71/1999, pasal 3. 
dalam Al-Qur'an surat Ar-Ruum ayat 21 tersebut adalah rasa tentram dan nyaman bagi jiwa raga dan kemantapan hati dalam menjalani hidup serta rasa aman, damai dan cinta kasih bagi kedua pasangan. ${ }^{23}$

Pemerintah Indonesia memandang penting program keluarga sakinah ini, yang ternyata mampu meningkatkan dan memperkokoh kehidupan masyarakat. Oleh karena itu, pemerintah Republik Indonesia melalui Menteri Agama Republik Indonesia menerbitkan Surat Keputusan Nomor 3 Tahun 1999 tentang Pembinaan Gerakan Keluarga Sakinah (GKS). Melalui program Pembinaan Gerakan Keluarga Sakinah ini, diharapkan angka keluarga miskin dan atau broken home di Indonesia dapat dikurangi, dan nilai-nilai keimanan, ketaqwaan, akhlak mulia serta budi luhur bangsa Indonesia dapat ditegakkan dengan baik dan benar sesuai dengan ciri khas bangsa Indonesia itu sendiri, yaitu ramah, sopan dan cinta damai.

Tujuan keluarga sakinah adalah:

a. Menanamkan nilai-nilai keimanan, ketaqwaan dan akhlak mulia melalui pendidikan agama dalam keluarga, masyarakat dan pendidikan formal.

b. Memberdayakan ekonomi umat melalui peningkatan kemampuan ekonomi keluarga dan masyarakat dalam upaya peningkatan ekonomi kerakyatan lainnya, serta memobilisasi potensi zakat, infaq dan shodaqoh.

c. Meningkatkan gizi keluarga, kesehatan keluarga dan masyarakat, serta meningkatkan upaya penanggulangan Penyakit Menular Seksual (PMS) dan HIV/ AIDS melalui pendekatan moral keagamaan. ${ }^{24}$

Dalam kenyataan dimasyarakat, berdasarkan Surat Keputusan Menteri Agama Republik Indonesia Nomor 3 Tahun 1999 tersebut, keluarga sakinah terdiri dari empat katagori, dimana pada setiap katagori mempunyai kriteria-kriteria tersendiri, yaitu: Pertama, Keluarga Sakinah I. Yaitu keluarga-keluarga yang telah dapat memenuhi kebutuhan dasar spiritual dan material secara minimal, tetapi masih belum dapat memenuhi

${ }^{23}$ Departemen Agama, Modul Fasilitator Kursus Calon Pengantin, (Jakarta: Dirjen BMI dan PUH, 2002), hal. 44.

24 Departemen Agama, Surat Keputusan Menteri Agama RI Nomor 3 Tahun 1999. 
kebutuhan sosial psikologisnya, seperti kebutuhan akan pendidikan, bimbingan keagamaan dalam keluarga dan belum dapat mengikuti interaksi sosial keagamaan dengan lingkungannya.

Adapun kriteria-kriteria dari Keluarga Sakinah I adalah: a) Perkawinannya sesuai dengan syariat dan UU Nomor 1 Tahun 1974, b) Keluarga memiliki surat nikah atau bukti lain sebagai bukti perkawinan yang sah, c) Mempunyai perangkat alat sholat, sebagai bukti melaksanakan sholat, d) Terpenuhi kebutuhan makanan pokok, sebagai bukti bukan miskin, f) Masih sering meninggalkan sholat, g) Masih percaya dengan perdukunan, h) Tidak datang dipengajian/majelis taklim, dan i) Rata-rata keluarga tamat atau memiliki ijazah SD.

Kedua, Keluarga Sakinah II. Yaitu keluarga-keluarga yang disamping telah dapat memenuhi kebutuhan hidupnya, juga telah mampu memahami pentingnya pelaksanaan ajaran agama serta bimbingan keagamaan dalam keluarga. Telah mampu mengadakan interaksi sosial keagamaan dengan lingkungannya, tetapi belum mampu menghayati serta mengembangkan nilai-nilai keimanan, ketaqwaan dan akhlakul karimah, infaq, wakaf, amal jariyah, menabung dan sebagainya.

Selain telah memenuhi kriteria Keluarga Sakinah I, keluarga Sakinah II, hendaknya: a) Tidak terjadi perceraian, kecuali sebab kematian atau hal sejenis lainnya yang mengharuskan terjadinya perceraian, b) Penghasilan keluarga melebihi kebutuhan pokok, sehingga bisa menabung, c) Rata-rata memiliki ijazah SMP, d) Memiliki rumah sendiri meskipun sederhana, e) Keluarga aktif dalam kegiatan kemasyarakatan dan sosial keagamaan, f) Mampu memenuhi standar makanan sehat (4 sehat 5 sempurna), dan g) Tidak terlibat perkara (tindakan kriminal).

Ketiga, Keluarga Sakinah III. Yaitu keluarga-keluarga yang dapat memenuhi seluruh kebutuhan keimanan, ketaqwaan, sosial psikologis, dan pengembangan keluarga, tetapi belum mampu menjadi suri tauladan bagi lingkungannya. Selain telah memenuhi kriteria Keluarga Sakinah II, keluarga tersebut hendaknya aktif dalam upaya meningkatkan kegiatan dan gairah keagamaan di masjid atau musholla maupun dalam keluarga.

Hal-hal yang bisa dilakukan dalam rangka mencapai tingkat Keluarga Sakinah ini, antara lain: a) Keluarga aktif menjadi pengurus kegiatan keagamaan dan sosial kemasyarakatan. b) Aktif memberi dorongan dan 
motivasi untuk meningkatkan kesehatan ibu dan anak serta kesehatan masyarakat pada umumnya. c) Rata-rata keluarga memiliki ijazah Sekolah Menengah Atas (SMA) keatas. d) Pengeluaran zakat, infaq, shodaqoh, dan wakaf senantiasa meningkat. e) Meningkatnya pengeluaran qurban.e ) Melaksanakan ibadah haji secara baik dan benar sesuai tuntunan agama dan ketentuan perundang-undangan yang berlaku.

Keempat, Keluarga Sakinah III Plus. Yaitu keluarga - keluarga yang dapat memenuhi seluruh kebutuhan keimanan, ketaqwaan, sosial psikologis dan pengembangan keluarga, serta mampu menjadi suri tauladan bagi lingkungannya.

Selain telah memenuhi kriteria Keluarga Sakinah III, keluarga tersebut hendaknya: a) Keluarga yang telah menunaikan ibadah haji dapat memenuhi kriteria haji mabrur. b) Menjadi tokoh agama, tokoh masyarakat dan tokoh organisasi yang dicintai oleh masyarakat dan keluarganya. c) Pengeluaran zakat, infaq, shodaqoh, jariyah, wakaf meningkat baik secara kualitatif maupun kuantitatif. d) Meningkatnya kemampuan keluarga dan masyarakat sekelilingnya dalam memenuhi ajaran agama. e) Keluarga mampu mengembangkan ajaran agamanya. f) Rata-rata anggota keluarga mempunyai ijazah sarjana. g) Nilai-nilai keimanan, ketaqwaan dan akhlakul karimah tertanam dalam kehidupan pribadi dan keluarganya. $\mathrm{h}$ ) Tumbuh berkembang perasaan cinta kasih sayang secara selaras, serasi dan seimbang dalam anggota keluarga dan lingkungannya. i) Mampu menjadi suri tauladan masyarakat sekaitarnya.

Indikator keluarga sakinah yang ditetapkan dengan Surat Keputusan Menteri Agama Republik Indonesia Nomor 3 Tahun 1999 sebagaimana tersebut diatas bersifat abstrak. Hal ini menjadikan sulitnya petugas untuk mengukur tingkat kesakinahan dari sebuah keluarga. Dengan demikian, perlu dilakukan pengkajian ulang atau evaluasi terhadap kebijakan tersebut.

Menurut Bastomi mengatakan bahwa ciri-ciri keluarga sakinah mawaddah warahmah itu, antara lain: ${ }^{25}$ 1) Memiliki kecenderungan kepada agama. 2) Saling menghormati dan menyayangi diantara yang muda dan yang tua. 3) Sederhana dalam belanja. 4) Santun dalam bergaul

${ }^{25}$ Wawancara dengan Drs.H. Bastomi (Ka KUA Kec. Kemiri Kab. Purworejo) tanggal 12 Januari 2014 di KUA Kec. Kemiri. 
dan saling introspeksi diri. 5) Suami isteri harus memfungsikan diri sesuai hak dan tanggungjawabnya masing-masing. 6) Suami isteri dalam bergaul memperhatikan hal-hal yang secara sosial dianggap patut (ma`ruf). Dalam rangka mewujudkan keluarga sakinah mawaddah wa rahmah perlu melalui proses yang panjang dan pengorbanan yang besar, hal ini dapat dilakukan dengan cara: 1) Pilihlah pasangan yang shaleh atau shalehah yang taat menjalankan perintah Allah dan sunnah Rasulullah SAW. 2) Pilihlah pasangan dengan mengutamakan keimanan dan ketaqwaannya dari pada kecantikan, kekayaan, maupun kedudukannya. 3) Pilihlah pasangan keturunan keluarga yang terjaga kehormatan dan nasabnya. 4) Niatkan saat menikah untuk beribadah kepada Allah SWT dan untuk menghindari hubungan yang dilarang Allah SWT. 6) Suami berusaha menjalankan kewajibannya sebagai seorang suami dengan dorongan iman, cinta, dan ibadah. 7) Istri berusaha menjalankan kewajibannya sebagai istri dengan dorongan ibadah dan mengharap ridha Allah semata. 8) Suami istri saling mengenali kekurangan dan kelebihan pasangannya, saling menghargai, merasa saling membutuhkan dan melengkapi, menghormati, mencintai, saling mempercayai kesetiaan masing-masing, saling keterbukaan dengan merajut komunikasi yang intens. 9) Berkomitmen menempuh perjalanan rumah tangga untuk selalu bersama dalam mengarungi badai dan gelombang kehidupan. 10) Suami mengajak anak dan istrinya untuk shalat berjamaah atau ibadah bersama-sama. 11) Suami istri selalu memohon kepada Allah agar diberikan keluarga yang sakinah mawaddah dan rahmah. 12) Suami secara berkala mengajak istri dan anaknya melakukan instropeksi diri untuk melakukan perbaikan dimasa depan.

Selanjutnya, untuk mencapai kehidupan keluarga sakinah, Chorus, seorang ahli psikolog Belanda, menyatakan bahwa ada tiga macam kebutuhan manusia yang harus dipenuhi untuk dapat hidup bahagia dan tenang, yaitu; kebutuhan vitologis, seperti; makan, minum dan kebutuhan kelamin, kebutuhan sosial kultural, seperti; pergaulan sosial, kebudayaan, dan kebutuhan metaphisis (religious), seperti; agama, moral dan falsafat hidup. ${ }^{26}$

26 Departemen Agama, Modul Fasilitator Kursusu Calon Pengantin, (Jakarta: Dirjen BMI dan PUH, 2002), hal. 43-44. 
Pandangan hukum Islam, pemuasan seksual antara seorang laki dan perempuan harus melalui ikatan perkawinan yang sah untuk membina dan mencapai ketenangan hati dan jiwa raga suami isteri. Ketenangan ini yang kemudian diartikan dengan rasa cinta dan kasih sayang. Sigmun Freud menyampaikan pandangan lain tentang teori kebutuhan. Menurutnya dari sekian banyak kebutuhan manusia maka kebutuhan pada pemuasan seksual lebih menonjol dan menentukan, malahan instink seksual merupakan dasar dan barometer bagi kebahagiaan seseorang. ${ }^{27}$

Usaha pemenuhan kebutuhan tersebut terkadang mengalami hambatan akibat berbagai faktor, seperti kesulitan ekonomi, perumahan, tingkat pendidikan yang rendah, kurangnya memahami akan tugas dan tanggung jawab sebagai seorang suami/istri, kurangnya pemahaman terhadap ajaran agama dan lain sebagainya. Selain memenuhi berbagai kebutuhan hidup, faktor kesiapan dan kematangan diri juga menjadi kekuatan untuk mencapai keluarga sakinah. Salah satunya adalah pendidikan, baik pendidikan formal maupun pendidikan non formal. Pendidikan yang memadahi khususnya dalam persiapan memasuki jenjang perkawinan, pasangan pengantin akan lebih siap dalam membentuk rumah tangga.

Dalam modul pendidikan agama dalam keluarga yang diterbitkan oleh Kementerian Agama, disebutkan bahwa cara dan usaha untuk mencapai keluarga yang sakinah atau bahagia adalah sebagai berikut: Pertama, faktor memilih jodoh. Memilih jodoh yang tepat sudah merupakan separuh dari suksesnya perkawinan. Untuk membina keluarga sakinah, amat ditentukan oleh pribadi kedua calon pengantin yang akan membentuk keluarga tersebut. Ibarat orang akan membangun sebuah rumah, maka memilih jodoh bagaikan membuat fondasi rumah tersebut. Salah dalam memilih jodoh, berarti salah dalam membuat fondasi suatu rumah. Oleh karena itu dalam memilih jodoh sebagai pasangan hidup harus betul-betul cermat dan selektif agar kelak dalam membina rumah tangga tidak terjadi penyesalan yang tiada gunanya.

Faktor-faktor yang harus dipertimbangkan dalam memilih pasangan adalah dilatarbelakangi oleh:28 a) Kekayaan,Masalah kekayaan (harta benda)

27 Ibid, hal. 44 .

28 Kementerian Agama, Modul Pelatihan Korp Penasehat Perkawinan dan Keuarga Sakinah, 
baik dari pihak seorang laki-laki maupun pihak perempuan, pandangan ini bukan pandangan yang sehat, terlebih apabila hal ini terjadi pada pihak laki-laki, karena hal tersebut akan menjatuhkan dirinya dibawah pengaruh perempuan dan hartanya. b) Keturunan (gelar atau pangkat), Hal inipun tidak akan berfaedah seperti yang diharapkan, malah dia akan bertambah hina dan dihinakan, karena gelar dan pangkat seseorang tidak akan berpindah pada orang lain. c) Kecantikan atau ketampanan, Hal ini sedikit lebih baik, asalkan dia tidak bersifat bangga dan sombong karena keadaan fisiknya itu. d) Agama dan akhlaknya, Apabila ketiga unsur diatas tidak terpenuhi karena sesuatu dan lain hal, maka agama dan akhlaklah yang paling baik untuk dikedepankan dan harus menjadi ukuran untuk pergaulan yang kekal serta dapat menjadi dasar kerukunan dan kemaslahatan rumah tangga, keluarga serta lingkungan sekitarnya. Disamping empat faktor tersebut di atas menurut penulis perlu ditambah dua faktor lagi sebagai modal dalam membina rumah tangga bahagia (sakinah), yaitu: faktor kesehatan dan faktor umur calon pasangan masing-masing.

Kedua, faktor kafa'ah. Kafa'ah artinya sepadan. Dalam memilih calon pasangan suami isteri, faktor kafa' ah atau sepadan sangat diperlukan. Hal ini dimaksudkan agar ada keseimbangan antara suami atau isteri dalam membina keluarga. Sepadan yang dimaksud adalah sepadan akhlak dan budi pekerti, ilmu pengetahuan, pendidikan dan sepadan keturunan. Hal ini merupakan faktor penting dalam sebuah perkawinan guna membentuk keluarga sakinah. Faktor kafa'ah (sekufu) tersebut dapat dijabarkan sebagai berikut: a) Seagama, Faktor seagama merupakan syarat mutlak dalam perjodohan, khususnya menurut agama Islam. Sebelum menjatuhkan pilihan, harus mengetahui lebih dahulu agama yang dianut sang calon. b) Sepadan akhlak dan moral, Baik buruknya keadaan seseorang, tergantung kepada budi bahasa dan akhlaknya. Seseorang dengan kecantikan dan keindahan lahiriah akan menjadi tidak berarti apabila tidak memiliki akhlak dan budi pekerti yang baik. c) Sepadan tentang pendidikan, Sepadan dalam pendidikan akan memudahkan jalinan komunikasi antar pasangan sehingga meminimalisir timbulnya konflik dalam keluarga. d) Sepadan tentang nasab/keturunan, Bahwa masing-masing pasangan berasal dari 
keturunan keluarga yang baik, yaitu baik tingkah laku dan akal budinya serta baik agama dan amal ibadahnya.

\section{Penutup}

Dari uraian di atas, dapat disimpulkan beberapa hal: 1) bahwa yang dimaksud dengan pembekalan pra nikah adalah proses transformasi perilaku dan sikap di dalam kelompok atau unit sosial terkecil dalam masyarakat terhadap calon mempelai. 2) Persiapan kearah perkawinan perlu dilakukan agar mereka yang akan memasukinya betul-betul siap, baik mental maupun material, terutama dalam mewujudkan fungsi-fungsi keluarga. 3) Pernikahan berkualitas adalah kondisi dimana dengan pernikahan dapat menghasilkan kebahagiaan, kesesuaian serta kestabilan pernikahan. Sedangkan tingkat kualitas pernikahan sendiri dipengaruhi oleh faktor seperti komposisi optimal keluarga, siklus kehidupan keluarga, kelayakan sosio ekonomi dan kesesuaian peran, faktor sumber daya sosial dan pribadi suami istri bahkan oleh kondisi pranikah. 4) Bahwa untuk mewujudkan keluarga sakinah mawaddah wa rahmah perlu melalui proses yang panjang dan pengorbanan yang besar. 5) Bahwa keluarga sakinah itu adalah keluarga yang semua anggota keluarganya merasakan cinta kasih, keamanan, ketentraman, perlindungan, bahagia, keberkahan, terhormat, dihargai, dipercaya dan dirahmati oleh Allah SWT.

\section{DAFTAR PUSTAKA}

Agama, Kementerian RI. 2000. AlQur'an dan Terjemahnya, Jakarta: CV. Kathoda.

2000. Undang-Undang Perkawinan Nomor 1 Tahun 1974, Jakarta: Dirjen Bimas Islam dan Urusan Haji.

2002. Modul Pendidikan Agama dalam Keluarga, Jakarta: Dirjen Bimas Islam dan urusan Haji.

1998. Kompilasi Hukum Islam di Indonesia, Jakarta: Dirjen Kelembagaan Agama Islam.

1997, Membina Keluarga Bahagia Sejahtera, Jakarta: Proyek Peningkatan Peranan Wanita. 
Affandi, Sulaiman. 2001. Peranan Petugas BP.4 terhadap Pembentukan Keluarga Sakinah Perspektif Manajemen Penyuluhan Islam dalam Keluarga, Tesis, Surakarta: UMS.

al Bukhari, al-Imam. 1993. Shahih al-Bukhari, Alih Bahasa Zaenudin Hamidy. Jilid 4, Cet. 2, Jakarta: Wijaya.

Andi Prastowo, Andi. 2011.Methode Penelitian Kualitatif dalam Perspektif Rancangan Penelitian, Yogjakarta: Ar-Ruzz Media.

Chamim, MS. 2004. Pengaruh Pendidikan Calon Pengantin Terhadap Kehidupan Rumah Tangga. Tesis, Surakarta: UMS.

Depdikbud. 2003.Undang-undang No. 20 Tahun 2003 tentang Sisdiknas, Jakarta: ttp.

Dirjen Bimas Islam dan Urusan Haji, 2003, Buku Pegangan Calon Pengantin, Jakarta: Dirjen Bimas Islam dan Urusan Haji.

Hadi, Sutrisno. 2004. Metodologi Research, jilid. 2, Yogyakarta: Andi Offset.

Hartini, Rahayu.1993. Perkawinan Usia Muda bagi Orang Islam dan Akibat Hukumnya. Tesis, Surakarta: UMS.

Hasan, Zamhari. 2003. Pengalaman Ajaran Agama dalam Siklus Kehidupan, Jakarta:

Departemen Agama RI.

Hawari, Dadang. 1992. Persiapan Perkawinan, Jakarta: ttp.

Jihad, Choirul. 2001. Panduan Keluarga Muslim, Semarang: BP4 Jawa Tengah.

Junaidi, Dedi. 2002. Bimbingan Perkawinan, Jakarta: Akademika Presindo

Kartini Kartono. 2000. Pengantar Metodelogy Research Sosiologi, Bandung: Alumni.

Moleong, Lexy. 2000. Metodologi Penelitian Kualitatif, Bandung: PT. Remaja Rosda Karya, cet. II.

Maskur Alie, Imam, dkk. 2001. Pemberdayaan Ekonomi Keluarga Sakinah, Jakarta: Dep. Agama RI.

Mardjoned, Ramlan. 2003. Keluarga Sakinah Rumahku Syurgaku, Jakarta: Media Da'wah.

Moleong, Lexy. 2000.Metodologi Penelitian Kualitatif, cet. II, Bandung: PT. Remaja Rosda Karya.

Muchtar, Kamal. 1987. Asas-Asas Hukum Islam tentang Perkawinan, Jakarta: Bulan Bintang.

Mudyahardjo, Redja. 2006. Filsafat Ilmu Pendidikan, Bandung: Rosda Karya. 
Muhajir, Noeng. 2002. Metodologi Penelitian Kualitatif, Edisi IV, Yogyakarta: Raka Sarasin.

Muhajir, Noeng. 2002. Metodologi Penelitian Kualitatif, Yogyakarta: Raka Sarasin, edisi IV.

Poerwadarminta. 1998. Kamus Besar Bahasa Indonesia, Jakarta: Balai Pustaka.

Rasyidi, Lili. 1991. Hukum Perkawinan dan Perceraian di Malaysia dan Indonesia, Bandung: Rosyda Karya.

Sabiq, Sayyid, 1998, Fiqih Sunnah, Bandung: PT Al-Maarif

Sahrodi, Jamil, dkk, 2005, Membedah Nalar Pendidikan Islam, Pengantar kearah Ilmu Pendidikan Islam, Cirebon: Pustaka Rihlah Group.

Shihab, Quraisy, 2001, Wawasan Al-Quran:Tafsir Maudlu'i atas Pelbagai Persoalan Umat, cet, III, Jakarta: Mizan.

Soekanto, Sarjono. 1992. Sosiologi suatu Pengantar, Cetakan XV, Jakarta: CV Rajawali.

Suprijanto. 2007. Pendidikan Orang Dewasa dari Teori hingga Aplikasi, Jakarta: Bumi Aksara.

Syaf, Mahyudin. 1998. Terjemahan Fiqih al-Sunnah, Jakarta: ttp.

Sanusi, dkk. 1992.Persiapan Menuju Perkawinan yang Lestari, Jakarta: Pustaka Antara.

Sugiyono. 2006.Metode Penelitian Pendidikan, Pendekatan Kuantitatif, Kualitatif dan RED, Bandung: Alfabeta.

Ariskunto, Suharsini. 2007.Prosedur Penelitian, Jakarta: PT Rineka Cipta.

Zahid, Moh. 2003. Dua Puluh Lima Tahun Pelaksanaan Undang-Undang Perkawinan, Jakarta: Kementerian Agama RI. 